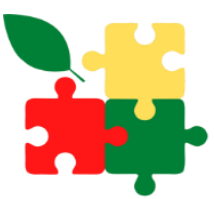

LITBANG

Edusaintech

\section{Jurnal Litbang Edusaintech (JLE)}

http://journal.pwmjateng.com/index.php/jle

\title{
GEOGRAPHICALLY WEIGHTED LOGISTIC REGRESSION (GWLR) WITH GAUSSLAN AD APTIVE KERNEL WEIGHTING FUNCTION, BISQUARE, AND TRICUBE IN CASE OF MALNUTRITION OF TODDLERS IN INDONESIA IN
}

Hanif Yisma Dhiya Ulhaq ${ }^{1 *}$, Rochdi Wasono ${ }^{2}$, Indah Manfaati Nur ${ }^{3}$

${ }^{12}$ Department of Statistics, Universitas Muhammadiyah ,Semarang, Indonesia

* Correspondence: hanifayisma19@gmail.com

\section{A B S T R A C T S}

Under-five child are children under the age of 5 years and included in the group vulnerable to nutrition. Malnutrition is a form of severity of chronic malnutrition. One of the factors causing malnutrition is geographical factor. Logistic Regression is an analysis used to find the relationship between response and predictor variables, but the results of the modeling are less precise if the data also contains spatial, so the appropriate analysis to overcome this is Geographically Weighted Logistic Regression (GWLR). The GWLR method is used to analyze spatial data where the characteristics of each region are considered. The variables used were malnutrition of children aged 0-59 months, the percentage of babies not getting vitamin $A$, the percentage of babies getting exclusive breastfeeding, and poor population. In the response variable, malnutrition of children aged 0-59 months with a binary category of 0 and 1 follows the Bernoulli distribution. In this study comparing 3 kernel weighting functions, namely Adaptive Gaussian, Adaptive Bisquare and Adaptive Tricube. The selection of the best model uses the smallest AICc value. The results of this study are that the GWLR model with the Adaptive Gaussian kernel weighting function is more appropriate to use where the optimum bandwidth value is 19 with a CV value of 7.361 and the resulting AICc value is 31.9082.

\section{A B S T R A K}

Balita merupakan anak dibawah umur 5 tahun dan masuk dalam golongan rawan gizi. Gizi buruk merupakan bentuk keparahan terjadinya kekurangan gizi yang terjadi secara menahun. Salah satu faktor penyebab gizi buruk adalah faktor geografis. Regresi Logistik merupakan analisis yang digunakan untuk mencari hubungan variabel respon dan prediktor, namun hasil pemodelannya kurang tepat apabila data juga mengandung spasial, sehingga analisis yang tepat untuk mengatasi hal tersebut adalah Geographically Weighted Logistic Regression (GWLR). Metode GWLR digunakan untuk menganalisis data spasial dimana karakteristik masingmasing wilayah dipertimbangkan. Variabel yang digunakan adalah gizi buruk balita usia 0-59 bulan $(\mathrm{Y})$, persentase bayi tidak mendapat vitamin A, persentase bayi mendapat ASI eksklusif, penduduk miskin $\left(\mathrm{X}_{3}\right)$. Pada variabel respon, gizi buruk balita usia 0-59 bulan dengan kategori biner yaitu 0 dan 1 mengikuti distribusi Bernoulli. Dalam penelitian ini membandingkan 3 fungsi pembobot kernel yaitu Adaptive Gaussian, Adaptive Bisquare dan Adaptive Tricube. Pemilihan model terbaik menggunakan nilai AICc terkecil. Hasil penelitian ini yaitu model GWLR dengan fungsi pembobot kernel Adaptive Gaussian lebih tepat digunakan dimana nilai bandwith optimum yang dihasilkan yaitu 19 dengan nilai CV sebesar 7.361 dan nilai AICc yang dihasilkan adalah 31.9082 .
A R T I C L E I N FO

Article History:

Received 07 Oct 2020

Revised 15 Oct 2020

Accepted 15 Oct 2020

Available online 180 ct 2020

\section{Keyword:}

Malnutrition,

Geographically Weighted Logistic Regression,

Adaptive Gaussian

\section{Keyword:}

Gizi Buruk,

Geographically Weighted Logistic Regression,

Adaptive Gaussian 


\section{PENDAHULUAN}

Balita merupakan anak dibawah umur 5 tahun (Muaris, 2006). Zat-zat gizi dalam jumlah banyak dibutuhkan oleh anak, karena hal itu diperlukan untuk pertumbuhan dan perkembangan mereka sehingga balita masuk dalam golongan rawan gizi (Notoatmodjo, 2003). Salah satu cara agar terhindar dari berbagai masalah gizi yang mempengaruhi kualitas hidup seseorang di masa yang akan datang yaitu dengan pemenuhan gizi yang cukup.

Permasalahan gizi pada masyarakat adalah masalah yang tersembunyi. Dampak gizi tidak terpenuhi akan menimbulkan kesakitan dan kematian (Adisasmito, 2008). Kekurangan gizi disebabkan oleh rendahnya akses masyarakat terhadap pangan, kurangnya kalori dan protein pada makanan ibu hamil, tidak diberinya kolostrum pada bayi yang baru lahir, pemberian Makanan Pendamping ASI (MP-ASI) pada bayi sebelum usianya 4-6 bulan, dll. (Dinkes Provinsi Jawa Barat, 2017).

Gizi buruk merupakan bentuk keparahan terjadinya kekurangan gizi yang terjadi secara menahun (Arisman dalam Alamsyah et al (2015)). Berdasarkan hasil Riskesdas (2018), proporsi status gizi buruk yang terjadi di Indonesia pada balita usia 0-23 bulan pada tahun 2007 sebesar 5.4\%, pada tahun 2013 naik menjadi 5.7\%, sedangkan pada tahun 2018 turun menjadi 3.9\%. Pada hasil Pemantauan Status Gizi (PSG) yang diselenggarakan juga oleh Kementerian Kesehatan RI pada tahun 2017, hasilnya tidak jauh berbeda dengan hasil Riskesdas tahun 2018 dimana persentase gizi buruk balita usia 0-23 bulan sebesar 3,8\%. Provinsi dengan persentase tertinggi gizi buruk pada usia balita $0-23$ bulan terdapat pada Nusa Tenggara Timur dan persentase terendah ada di Provinsi Kepualauan Riau (Kemenkes RI, 2019). Dibandingkan dengan hasil PSG tahu lalu (2016), persentase gizi buruk Indonesia sebesar 3,4\% sehingga ada kenaikan $0,4 \%$ dari tahun 2016 sampai tahun 2017.

Pemerintah Indonesia sudah melakukan upaya pencegahan dan penangan masalah gizi dengan cara menerapkan gizi seimbang. Hal ini tercantum dalam Peraturan Menteri Kesehatan Nomor 23 Tahun 2014 tentang Upaya Perbaikan Gizi. Upaya penanganan gizi buruk tidak bisa digeneralisir di setiap wilayah karena banyak faktor yang mempengaruhi berbedabeda. Salah satu faktornya adalah faktor geografis (Anggarini dan Purhadi, 2012).

Kesimpulan yang kurang tepat akan terjadi apabila menggunakan model regresi linier sebagai alat analisis data yang di dalamnya mengandung efek spasial. Dalam analisis data spasial menggunakan regresi spasial hasil pemodelannya kurang tepat jika mengandung efek keragaman spasial. Sehingga dilakukan pengembangan metode Geographically Weighted Regression (GWR). Penghitungan parameter dilakukan di setiap titik wilayah geografis sehingga parameter regresinya berbeda-beda.

Metode GWR kemudian dikembangkan kembali dengan memadukan dengan metode regresi lain. Atkinson et al dalam Hasriana et al (2016) menyatakan pengembangan GWR berfungsi untuk menduga model dari data yang memiliki variabel respon berkategori biner melalui model logistik. Metode ini dinamakan Geographically Weighted Logistic Regression (GWLR) hasil pengembangan Fotheringham et al (2002).

Metode GWLR merupakan metode yang diasumsikan data berdistribusi Bernoulli dimana penaksir parameter didapatkan dari metode Maximum Likelihood Estimation (MLE). Dalam menentukan unsur pembobot digunakan Fungsi Kernel sesuai bandwith optimal sesuai dengan kondisi data. Pembobot fungsi kernel ada 3, yaitu Gaussian, Bisquare dan Tricube (Dwinata, 2012).

Penelitian sebelumya dengan metode GWLR dilakukan oleh Anggarini dan Purhadi (2012) dimana meneliti tentang prevalensi balita kurang gizi dengan hasil fungsi pembobot yang sesuai dari penelitian tersebut adalah Adaptive Bisquare Kernel, Fatimah et al (2015), yaitu melakukan pemodelan risiko penyakit pneumonia pada balita di Provinsi Jawa Timur dan hasil pembobot yang sesuai adalah Adaptive Gaussian Kernel, Umyana (2018) melakukan perbandingan regresi logistik dengan GWLR untuk pemodelan rasio gini di Jawa Timur, dimana fungsi pembobot yang sesuai adalah Fixed Bisquare Kernel. Penelitian sebelumnya yang menggunakan fungsi 
pembobot lain yaitu Tricube belum pernah digunakan untuk metode GWLR.

Beberapa penelitian yang menggunakan fungsi pembobot Tricube yaitu Destyanugraha dan Kurniawan (2017) menggunakan metode GWPR pada kasus Angka Kematian Ibu di Indonesia, Fadli et al (2018) menggunakan metode GWR pada kasus Angka Kematian Ibu (AKI) di Kabupaten Kuta Kartanegara, dan penelitian Nugroho dan Slamet (2018) menggunakan metode GWR pada kasus kemiskinan di Provinsi Jawa Tengah.

Berdasarkan uraian di atas maka penelitian ini bertujuan untuk mengembangkan penelitian terdahulu yaitu pemodelan kasus gizi buruk balita di Indonesia tahun 2018 dimana metode yang digunakan adalah Geograohically Weighted Logistic Regression (GWLR), dimana fungsi pembobot yang digunakan pada GWLR adalah fungsi kernel Adaptive Gaussian, Adaptive Bisquare, dan Adaptive Tricube, kemudian mncari mencari model terbaik yang dihasilkan.

\section{TINJAUAN PUSTAKA}

\section{Regresi Logistik}

Model regresi logistik yang variabel responnya berskala kategori biner atau memiliki dua kategori bernilai 0 dan 1 disebut dengan regresi logistik biner (Agresti, 2013). Karena hasil observasi variabel respon memiliki dua kategori, maka mengikuti distribusi Bernoulli dengan fungsi kepadatan peluang sebagai berikut (Hosmer dan Lemeshow, 1989):

$$
\begin{aligned}
& P(Y=y)=\pi^{y}(1-\pi)^{1-y} \text { dimana } y=-0,1 \\
& \text { Jika y }=0, \text { maka } P(Y=0)=1-\pi \\
& \text { Jika } y=1, \text { maka } P(Y=1)=\pi \text { dan } \\
& E(Y)=\pi, \operatorname{var}(Y)=\pi(1-\pi)
\end{aligned}
$$

Rata-rata bersyarat dari $\mathrm{y}$, apabila nilai $\mathrm{x}$ adalah $\pi(x)=E(y \mid x)$. Model regresi logistik berganda berfungsi jika jumlah variabel prediktor yang digunakan pada regresi logistik lebih dari satu. Maka model regresi logistik dengan $\mathrm{k}$ variabel yaitu :

$$
\pi(x)=\frac{\exp \left(\beta_{0}+\beta_{1} x_{1}+\cdots+\beta_{k} x_{k}\right)}{1+\exp \left(\beta_{0}+\beta_{1} x_{1}+\cdots+\beta_{p} x_{p}\right)}
$$

Maka transformasi logit pada $\pi(\mathrm{x})$ menjadi:

\section{Multikolinieritas}

Multikolinieritas merupakan adanya korelasi antar variabel prediktor apabila dalam model regresi menggunakan lebih dari satu variabel prediktor.

Salah satu kriteria untuk mendeteksi adanya multikolinieritas dengan menggunakan nilai VIF (Variance Inflation Factors). Terjadi multikolinieritas apabila nilai $\mathrm{VIF}>10$. Rumus mendapat nilai VIF yaitu,

$$
V I F=\frac{1}{1-R_{j}^{2}}
$$

Dimana $R_{j}^{2}$ merupakan koefisien determinasi.

\section{Heterogenitas Spasial}

Dalam menunjukkan apakah ada heterogenitas atau keragaman daerah dalam spasial, maka digunakan uji Breusch-Pagan (Anselin, 1988).

Hipotesis yang diuji adalah :

$\mathrm{H}_{0}$ : Tidak terdapat heterogenitas spasial

$\mathrm{H}_{1}$ : Terdapat heterogenitas spasial

Rumus Uji Breusch-Pagan:

$$
B P=\frac{1}{2} f^{T} Z\left(Z^{T} Z\right)^{-1} Z^{T} f \sim \chi_{p}^{2}
$$

Dimana vector $\mathrm{f}$ adalah:

Keterangan :

$$
f_{i}=\left(\frac{e_{i}^{2}}{\sigma^{2}}-1\right)
$$

$e_{i}^{2} \quad$ : galat observasi ke $-\mathrm{i}$

$\mathrm{Z} \quad$ : matriks berukuran $\mathrm{n} \times(\mathrm{p}+1)$ yang berisi vektor yang distandarkan untuk tiap observasi

Keputusan $\mathrm{H}_{0}$ ditolak apabila nilai $\mathrm{BP}>\chi_{p}^{2}$

\section{Geographically Weighted Regression (GWR)}

GWR atau Geographically Weighted Regression merupakan sebuah kontribusi baru untuk proses pemodelan heterogen spasial. Dalam Fotheringham et al (2002) model GWR dapat ditulis sebagai berikut:

$$
\begin{aligned}
& y_{i}=\beta_{0}\left(u_{i}, v_{i}\right)+\sum_{j=1}^{k} \beta_{j}\left(u_{i}, v_{i}\right) x_{i j}+\varepsilon_{i}, \\
& \text { dengan } i=1,2, \ldots, \mathrm{n}
\end{aligned}
$$

dimana,

$y_{i}$ : nilai observasi variabel respon ke- $i$

$x_{i j}$ : nilai observasi variabel prediktor ke-j pada pengmatan ke-i

$\beta_{0}\left(u_{i}, v_{i}\right)$ : nilai intercept model regresi

$\beta_{j}\left(u_{i}, v_{i}\right)$ : koefisien regresi $\mathrm{j}=0,1,2, \ldots, \mathrm{k}$

$u_{i}, v_{i}:$ titik koordinat lokasi $i$

$\varepsilon_{i}$ : nilai error regresi ke- $i$ 


\section{Fungsi Pembobot Spasial}

Fungsi pembobot yaitu berperan penting dalam melalukan penaksiran parameter. Titiktitik yang dekat dengan suatu lokasi $i$ akan lebih mempengaruhi penaksiran parameter di suatu lokasi tersebut (Leung et al, 2000). Dalam menentukan pembobot maka dilakukan penghitungan dengan cara apabila lokasi $j$ terdapat pada koordinat $\left(\mathrm{u}_{\mathrm{i}}, \mathrm{v}_{\mathrm{i}}\right)$ akan didapatkan jarak euclidean antara $i$ dan lokasi $j$. Perumusan jarak euclidean adalah sebagai berikut:

$$
d_{i j}=\sqrt{\left(u_{i} u_{j}\right)^{2}+\left(v_{i} v_{j}\right)^{2}}
$$

Fungsi kernel merupakan metode yang biasa digunakan, jenis-jenisnya yaitu:

a. Fungsi Adaptive Gaussian Kernel

$$
w_{i}\left(u_{i}, v_{i}\right)=\exp \left[-\left(\frac{d_{i j} / h_{(q)}}{2}\right)^{2}\right]
$$

b. Fungsi Adaptive Bi-square Kernel

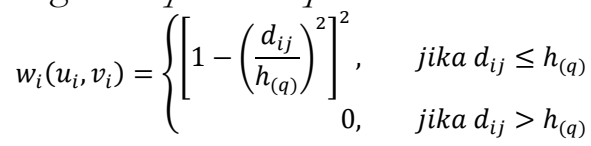

c. Fungsi Adaptive Tricube Kernel

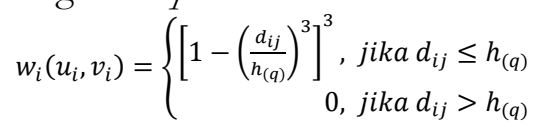

Dalam pencarian pembobot lokasi berdasarkan jarak euclidean $\mathrm{d}_{\mathrm{ij}}$ dan bandwith, dimana bandwith (b) merupakan parameter non negatif dan disebut dengan parameter penghalus. Bandwith optimum dipilih melalui pendekatan least square, dimana pendekatan ini menggunakan metode Cross Validation (CV). Rumus CV yaitu,

$$
C V(h)=\sum_{i=1}^{n}\left(y_{i}-\hat{y}_{\neq i}(h)\right)^{2}
$$

Dimana $\hat{y}_{\neq i}(h)$ merupakan nilai penaksir dari $y_{i}$ dimana pengamatan di lokasi $u_{i}, v_{i}$ selama proses estimasi dihilangkan. Nilai bandwith optimum dihasilkan dari nilai $\mathrm{h}$ yang menghasilkan nilai CV paling kecil.

\section{Geographically Weighted Logistic Regression (GWLR)}

Geographically Weighted Logistic Regression merupakan sebuah metode penggabungan antara Geographically Weighted Regression (GWR) dengan Regresi Logistik. Model GWLR secara matematis sebagai berikut:

$$
\pi x_{i}=\frac{\exp \left(\sum_{j=0}^{p} \beta_{j}\left(u_{i}, v_{i}\right) x_{i j}\right.}{1+\exp \left(\sum_{j=0}^{p} \beta_{j}\left(u_{i}, v_{i}\right) x_{i j}\right)}
$$

Dimana $x_{i j}$ merupakan nilai observasi prediktor pada lokasi $u_{i}, v_{i}, \beta_{j}\left(u_{i}, v_{i}\right)$ adalah koefisien regresi untuk setiap lokasi $u_{i}, v_{i}$, dan $\mathrm{p}$ merupakan banyaknya parameter variabel prediktor.

Pengujian serentak variabel prediktor diuji secara bersama-sama pada model GWLR. Hipotesis yang digunakan yaitu,

$$
\mathrm{H}_{0}: \beta_{1}\left(u_{i} v_{i}\right)=\beta_{2}\left(u_{i} v_{i}\right)=
$$

$\cdots \beta_{p}\left(u_{i} v_{i}\right)=0$

$\mathrm{H}_{1}$ : paling tidak ada satu $\beta_{k}\left(u_{i} v_{i}\right) \neq$ $0 ; k=1,2, \ldots, p$

Statistik uji yang digunakan adalah :

$$
D=\left(\beta\left(u_{i} v_{i}\right)\right)=-2 \ln \left[\frac{L(w)}{L(\pi)}\right]
$$

Kriteria pengujiannya yaitu tolak $\mathrm{H}_{0}$ apabila nilai $\mathrm{D}\left(\beta_{1}\left(u_{i} v_{i}\right)\right)>x^{2}{ }_{v(\alpha)}$

Pengujian parameter model GWLR maka hipotesis yang digunakan yaitu,

$$
\begin{aligned}
& \mathrm{H}_{0}: \beta_{k}=\beta_{k}\left(\mathrm{u}_{\left.\mathrm{i}, \mathrm{v}_{\mathrm{i}}\right)}=0\right. \\
& \mathrm{H}_{1}: \beta_{k}\left(\mathrm{u}_{\left.\mathrm{i}, \mathrm{v}_{\mathrm{i}}\right) \neq 0}\right.
\end{aligned}
$$

Dimana statistik uji yang digunakan yaitu,

$$
z=\frac{\beta_{k}\left(u_{i} v_{i}\right)}{\operatorname{se}\left(\beta_{k}\left(u_{i} v_{i}\right)\right)}
$$

Kriterian pengujiannya adalah tolak $\mathrm{H}_{0}$ apabila nilai $\mid$ Zhit $\mid>Z_{\alpha / 2}$

\section{Pemilihan Model Terbaik}

Dalam memilih model terbaik model GWLR menggunakan nilai AICc atau Corrected Akaike Information Criterion (AICc). AICc memberikan hasil yang lebih baik daripada AIC jika jumlah sampel (n) dibagi dengan jumlah parameter yang diestimasi berjumlah $\leq 40$ (Sheather, 2009).

Dimana,

$$
\begin{aligned}
& A I C=-2 \ln (L)+2 k \\
& A I C C=A I C+\frac{2 k^{2}+2 k}{n-k-1}
\end{aligned}
$$

Keterangan :

$\mathrm{n}$ : jumlah data

$\mathrm{k}$ : jumlah parameter yang diestimasi dalam model regresi

$\mathrm{L}$ : nilai maksimum fungsi likelihood

\section{METODE}

\section{Sumber Penelitian}

Data yang digunakan dalam penelitian ini berjenis data sekunder, yaitu data yang 
diperoleh dari publikasi "Data dan Informasi Profil Kesehatan Indonesia 2018" yang diterbitkan oleh Kementerian Kesehatan Republik Indonesia dan "Statistik Indonesia 2019" yang diterbitkan oleh Badan Pusat Statistik, dimana objek penelitian yang digunakan adalah 34 Provinsi di Indonesia.. Data Longitude dan Latitude tiap Provinsi di Indonesia di dapat di wmw.googlemaps.com.

\section{Variabel Penelitian}

Variabel respon yang digunakan adalah status gizi balita usia 0-23 bulan di Indonesia tahun 2018. Variabel prediktor yang digunakan dalam penelitian ini berjumlah 3 variabel, yaitu persentase balita tidak mendapatkan vitamin A, persentase bayi mendapat ASI eksklusif, dan kemiskinan.

\section{Langkah-Langkah Penelitian}

a. Melakukan analisis deskriptif persentase gizi buruk balita usia 0-23 bulan di Indonesia dengan menggunakan peta tematik.

b. Melakukan uji multikolinieritas untuk mengetahui adanya hubungan antara variabel prediktor.

c. Melakukan uji breusch-pagan untuk mengetahui adanya heterogenitas spasial pada data.

d. Menghitung jarak euclidean antara lokasi observasi berdasarkan letak geografis (longitude dan latitude).

e. Menentukan bandwith optimum semua lokasi pengamatan dengan menggunakan Cross Validation (CV).

f. Menghitung matriks pembobot dengan memasukkan jarak euclidean dan bandwith ke dalam fungsi kernel.

g. Menaksir parameter model Geographically Weighted Logistics Regression (GWLR).

h. Melakukan pengujian parameter model GWLR.

i. Membandingkan nilai AICc masing-masing model untuk mendapatkan model terbaik.

\section{HASIL DAN PEMBAHASAN}

1. Penyebaran Gizi Buruk Balita Usia 023 bulan di Indonesia Tahun 2018

Berdasarkan hasil Riset Kesehatan Dasar (RISKESDAS) tahun 2018, rata-rata persentase gizi buruk balita Indonesia usia 0-23 bulan sebesar 3.8\%. Hasil tersebut tidak jauh dari hasil
Pemantauan Status Gizi (PSG) yang dilakukan oleh Kementerian Kesehatan (Kemenkes) pada tahun 2017, dengan hasil persentase gizi buruk balita sebesar 3.8\%. Provinsi dengan persentase tertinggi gizi buruk ada di Provinsi Maluku dengan nilai sebesar $7.4 \%$, sedangkan persentase terendah ada di Provinsi Bali yaitu sebesar $2 \%$.

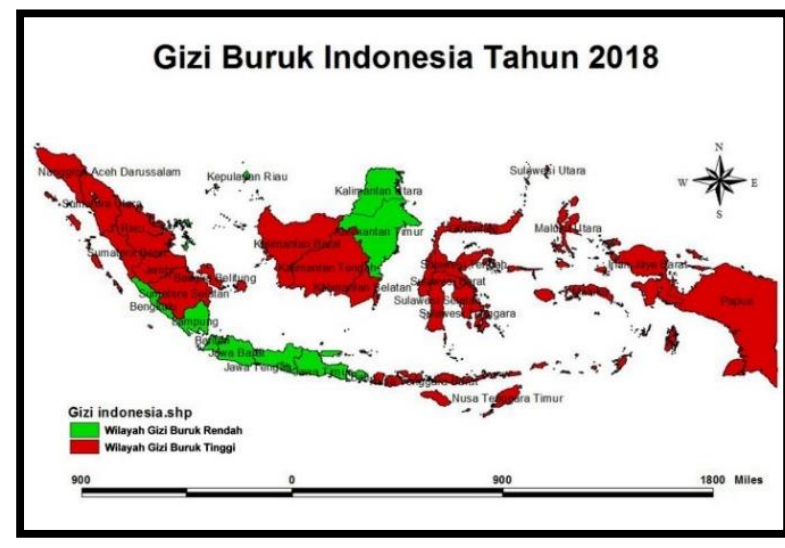

Gambar 1. Peta Status Gizi Balita di Indonesia Tahun 2018

Tabel 1. Rata-Rata Persentase Gizi Buruk Balita di Indonesia Tahun 2018

\begin{tabular}{cccc}
\hline $\begin{array}{c}\text { Status } \\
\text { Gizi Buruk }\end{array}$ & Kategori & $\begin{array}{c}\text { Jumlah } \\
\text { Provinsi }\end{array}$ & $\begin{array}{c}\text { Rata-Rata } \\
\text { Persentase } \\
\mathbf{( \% )}\end{array}$ \\
\hline Rendah & 0 & 12 & 2.84 \\
Tinggi & 1 & 22 & 5.31 \\
\hline
\end{tabular}

Berdasarkan tabel 1, ada 12 Provinsi di Indonesia yang termasuk dalam kategori daerah gizi buruk rendah dimana nilai persentasenya kurang dari 3.9\%. Pada tabel 4.1, rata-rata persentase pada kategori ini sebesar 2.84\%. Beberapa Provinsi yang masuk dalam kategori ini yaitu, Provinsi Bengkulu, Provinsi Lampung, Provinsi Jawa Tengah, Provinsi Jawa Barat, dll. Pada 22 Provinsi lainnya masuk dalam kategori daerah gizi buruk tinggi dimana nilai persentasenya lebih dari 3.9\%. Rata-rata persentase pada kategori ini sebesar 5.31\%. Beberapa Provinsi yang masuk dalam kategori ini adalah Provinsi Aceh, Provinsi Riau, Provinsi Kalimantan Barat, Provinsi Maluku, dll.

\section{Uji Multikolinieritas}


Berikut hasil uji VIF dari ketiga variabel prediktor yang digunakan:

Tabel 2. Nilai VIF Variabel Prediktor

\begin{tabular}{cc}
\hline Variabel & Nilai VIF \\
\hline X1 & 1.020 \\
X2 & 1.020 \\
X3 & 1.002 \\
\hline
\end{tabular}

Berdasarkan tabel 4.2, seluruh variabel prediktor memiliki nilai VIF yang kurang dari 10, sehingga tidak terjadi multikolinieritas.

\section{Uji Breusch Pagan}

Berikut hasil uji BP yang dihasilkan:

Tabel 3 Hasil Uji Breusch-Pagan

\begin{tabular}{cc}
\hline Uji & $p$-value \\
\hline Breusch Pagan & $\mathbf{0 . 0 6 4}$ \\
\hline
\end{tabular}

Berdasarkan hasil pengujian pada tabel 3, nilai p-value yang dihasilkan sebesar 0.0643. Nilai tersebut kurang dari $\alpha=10 \%$ yang digunakan, sehingga terjadi heterogenitas spasial. Selanjutnya akan dilakukan analisis lebih lanjut menggunakan metode Geographically Weighted Logistic Regression (GWLR).

4. Jarak Euclidean dan Bandwith

\section{Optimum}

Jarak euclidean berfungsi untuk menentukan urutan wilayah-wilayah lainnya yang berdekatan Aceh

dengan suatu wilayah $i$, dan akan mendapatkan Sumatera Utara urutan tetangga terdekat dari keseluruhan: wilayah pengamatan.

Tabel 4. Hasil Bandwith Optimum Setiap Pembobot

\begin{tabular}{ccc}
\hline Pembobot & $\begin{array}{c}\text { Bandwith } \\
\text { Optimum }\end{array}$ & CV Score \\
\hline Gaussian & 19 & 7.361 \\
Bisquare & 31 & 7.712 \\
Tricube & 31 & 7.312 \\
\hline
\end{tabular}

Tabel 5. Nilai Bandwith (dalam km) Tiap Provinsi di Indonesia

\begin{tabular}{llll} 
Wilayah & $\begin{array}{l}\text { Adaptive } \\
\text { Gaussian }\end{array}$ & $\begin{array}{l}\text { Adaptive } \\
\text { Bisquare }\end{array}$ & $\begin{array}{c}\text { Adaptive } \\
\text { Tricube }\end{array}$ \\
\hline
\end{tabular}

\begin{tabular}{cccc} 
Aceh & 19.773 & 31.216 & 31.216 \\
& 16.578 & 28.269 & 28.26 \\
Sumatera & $:$ & $:$ & $:$ \\
Utara & $:$ & $:$ & $:$ \\
$:$ & 26.903 & 36.659 & 36.659 \\
$:$ & & & \\
Papua & & & \\
\hline
\end{tabular}

Contoh pembentukan fungsi pembobot Adaptive Gaussian Kernel antara Provinsi Maluku $\left(u_{31}, v_{31}\right)$ dengan Provinsi Papua Barat $\left(u_{34}, v_{34}\right)$, yaitu:

$$
w_{34}=\exp \left[\left(-\frac{3.577 / 21.385}{2}\right)^{2}\right]
$$

Contoh pembentukan fungsi pembobot Adaptive Bisquare Kernel antara Provinsi Maluku $\left(u_{31}, v_{31}\right)$ dengan Provinsi Sulawesi Barat $\left(u_{30}, v_{30}\right)$, yaitu:

$$
\begin{gathered}
w_{30}=\left[1-\left(\frac{8.647}{18.552}\right)^{2}\right]^{2} \\
w_{30}=0.427
\end{gathered}
$$

Contoh pembentukan fungsi pembobot Adaptive Tricube Kernel antara Provinsi Maluku $\left(u_{31}, v_{31}\right)$ dengan Provinsi Papua $\left(u_{34}, v_{34}\right)$, yaitu:

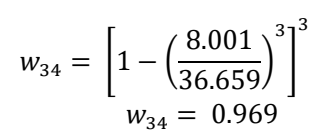

Tabel 6 Hasil Pembobot pada Provinsi Maluku

\begin{tabular}{lccc} 
Wilayah & $\begin{array}{c}\text { Adaptive } \\
\text { Gaussian }\end{array}$ & $\begin{array}{c}\text { Adaptive } \\
\text { Bisquare }\end{array}$ & $\begin{array}{c}\text { Adaptive } \\
\text { Tricube }\end{array}$ \\
\hline Aceh & 0 & 0 & 0 \\
Sumatera Utara & 0 & 0 & 0 \\
$:$ & $:$ & $:$ & $:$ \\
: & $:$ & $:$ & $:$ \\
Papua & 1.022 & 0.907 & 0.969
\end{tabular}

\section{Pengujian Paramater Model GWLR dengan Fungsi Pembobot Adaptive Gaussian Kernel}

Berdasarkan hasil nilai deviance sebesar 31.966, dimana nilai tersebut lebih besar dari nilai $\chi^{2}$ tabel yaitu 6.251 sehingga terdapat minimal ada satu variabel prediktor yang berpengaruh signifikan terhadap kasus gizi buruk balita di Indonesia. 
Tabel 7 Hasil Estimasi Parameter Model GWLR Adaptive Gaussian Kernel Provinsi Maluku

\begin{tabular}{ccccc}
\hline $\begin{array}{c}\text { Param } \\
\text { eter }\end{array}$ & Estimasi & $\begin{array}{c}\text { Standar } \\
\text { Error }\end{array}$ & $\mathrm{Z}_{\text {hit }}$ & $\begin{array}{c}\text { Odds } \\
\text { Ratio }\end{array}$ \\
\hline$\beta_{0}$ & 0.808 & 1.027 & 0.786 & 2.243 \\
$\beta_{1}$ & -0.025 & 0.012 & $\mathbf{- 2 . 0 9 3}$ & 0.976 \\
$\beta_{2}$ & 0.035 & 0.007 & $\mathbf{4 . 9 8 1}$ & 1.036 \\
$\beta_{3}$ & 0.388 & 0.572 & 0.679 & 1.474 \\
\hline
\end{tabular}

Berdasarkan tabel 7 maka diperoleh Model GWLR Provinsi Maluku dengan Pembobor Adaptive Gaussian Kernel yaitu:

$$
\hat{\pi}=\frac{\exp \left(0.808-0.025 X_{1}+0.035 X_{2}-0.388 X_{3}\right)}{1+\exp \left(0.808-0.025 X_{1}+0.035 X_{2}-0.388 X_{3}\right)}
$$

Maka fungsi logitnya adalah sebagai berikut $g(x)=0.808-0.025 X_{1}+0.035 X_{2}-0.388 X_{3}$

Pada penelitian ini menggunakan $\alpha=10 \%$, sehingga nilai Ztabel yang dihasilkan adalah 1.64. Variabel prediktor yang signifikan ditunjukkan dengan nilai | Zhitung $\mid>$ Ztabel. Sehingga variabel prediktor yang signifikan pada model GWLR Provinsi Maluku yaitu persentase balita yang tidak mendapatkan Vitamin A $\left(\mathrm{X}_{1}\right)$ dan persentase bayi yang mendapatkan ASI eksklusif $\left(\mathrm{X}_{2}\right)$.

\section{Pengujian Paramater Model GWLR dengan Fungsi Pembobot Adaptive Bisquare Kernel}

Berdasarkan nilai deviance yang dihasilkan sebesar 27.311, dimana nilai tersebut lebih besar dari nilai $\chi^{2}$ tabel yaitu 6.251 sehingga terdapat minimal ada satu variabel prediktor yang berpengaruh signifikan terhadap kasus gizi buruk balita di Indonesia.

Tabel 8 Hasil Estimasi Parameter Model GWLR Provinsi Maluku dengan Pembobot Adaptive Bisquare Kernel

\begin{tabular}{ccccc}
\hline Parameter & Estimasi & $\begin{array}{c}\text { Standar } \\
\text { Error }\end{array}$ & $\mathrm{Z}_{\text {hit }}$ & $\begin{array}{c}\text { Odds } \\
\text { Ratio }\end{array}$ \\
\hline$\beta_{0}$ & -0.253 & 2.011 & -0.126 & 0.776 \\
$\beta_{1}$ & -0.015 & 0.025 & -0.592 & 0.985 \\
$\beta_{2}$ & 0.039 & 0.009 & $\mathbf{4 . 5 4 8}$ & 1.040 \\
$\beta_{3}$ & 0.666 & 1.198 & 0.556 & 1.946 \\
\hline
\end{tabular}

Berdasarkan tabel 4.8 maka diperoleh Model GWLR Provinsi Maluku dengan Pembobor Adaptive Bisquare Kernel yaitu:

$$
\hat{\pi}=\frac{\exp \left(-0.253-0.015 X_{1}+0.039 X_{2}-0.666 X_{3}\right)}{1+\exp \left(-0.253-0.015 X_{1}+0.039 X_{2}-0.666 X_{3}\right)}
$$

Maka fungsi logitnya adalah sebagai berikut $g(x)=-0.253-0.015 X_{1}+0.039 X_{2}-0.666 X_{3}$

Taraf signifikansi yang digunakan adalah $\alpha=10 \%$, sehingga nilai Ztabel yang dihasilkan adalah 1.64. Variabel prediktor yang signifikan ditunjukkan dengan nilai | Zhitung | > Ztabel. Sehingga bariabel prediktor yang signifikan pada model GWLR Provinsi Maluku dengan pembobot Adaptive Bisquare Kerenel yaitu persentase bayi yang mendapatkan ASI eksklusif $\left(\mathrm{X}_{2}\right)$.

\section{Pengujian Paramater Model GWLR dengan Fungsi Pembobot Adaptive Bisquare Kernel}

Berdasarkan nilai deviance yang dihasilkan sebesar 28.948, dimana nilai tersebut lebih besar dari nilai $\chi^{2}$ tabel yaitu 6.251 sehingga terdapat minimal ada satu variabel prediktor yang berpengaruh signifikan terhadap kasus gizi buruk balita di Indonesia.

Tabel 9 Pengujian Parameter Model GWLR Provinsi Maluku dengan Pembobot Adaptive Tricube Kernel

\begin{tabular}{ccccc}
\hline $\begin{array}{c}\text { Para } \\
\text { meter }\end{array}$ & Estimasi & $\begin{array}{c}\text { Standar } \\
\text { Error }\end{array}$ & $\mathrm{Z}_{\text {hit }}$ & $\begin{array}{c}\text { Odds } \\
\text { Ratio }\end{array}$ \\
\hline$\beta_{0}$ & -0.737 & 1.545 & -0.477 & 0.479 \\
$\beta_{1}$ & -0.009 & 0.018 & -0.485 & 0.991 \\
$\beta_{2}$ & 0.047 & 0.013 & $\mathbf{3 . 7 1 5}$ & 1.048 \\
$\beta_{3}$ & 0.757 & 1.153 & 0.657 & 2.132
\end{tabular}

Berdasarkan tabel 9 maka diperoleh Model GWLR Provinsi Maluku dengan Pembobor Adaptive Tricube Kernel yaitu:

$$
\hat{\pi}=\frac{\exp \left(-0.737-0.009 X_{1}+0.047 X_{2}+0.757 X_{3}\right)}{1+\exp \left(-0.737-0.009 X_{1}+0.047 X_{2}+0.757 X_{3}\right)}
$$

Maka fungsi logitnya adalah sebagai berikut $g(x)=-0.737-0.009 X_{1}+0.047 X_{2}+0.757 X_{3}$ Taraf signifikansi yang digunakan adalah $\alpha=10 \%$, sehingga nilai Ztabel yang dihasilkan adalah 1.64. Variabel prediktor yang signifikan ditunjukkan dengan nilai | Zhitung | $>$ Ztabel. Sehingga variabel prediktor yang signifikan pada model GWLR Provinsi Maluku dengan pembobot Adaptive Tricube Kerenel yaitu persentase bayi yang mendapatkan ASI eksklusif $\left(\mathrm{X}_{2}\right)$. 


\section{Pemilihan Model Terbaik}

Berikut merupakan nilai AICc dari model GWLR dengan masing-masing

pembobot yang digunakan:

Tabel 10. Nilai AICc Model GWLR

\begin{tabular}{cc}
\hline Pembobot Model GWLR & Nilai AICc \\
\hline GWLR (Adaptive Gaussian) & $\mathbf{3 1 . 9 0 8 2}$ \\
GWLR (Adaptive Bisquare) & 34.8451 \\
GWLR (Adaptive Tricube) & 33.7456 \\
\hline
\end{tabular}

Berdasarkan tabel 4.10, nilai AICc pada model GWLR dengan pembobot Adaptive Gaussian Kernel memiliki nilai terkecil yaitu sebesar 31.9082. Sehingga model terbaik yang dihasilkan untuk kasus gizi buruk Indonesia tahun 2018 menggunakan model GWLR dengan pembobot Adaptive Gaussian Kernel.

\section{KESIMPULAN}

1. Provinsi dengan persentase gizi buruk balita usia 0-23 bulan tahun 2018 tertinggi di Indonesia ada di Provinsi Maluku dengan angka sebesar $7.4 \%$ sedangkan persentase terendah ada di Provinsi Bali dengan angka sebesar 2\%. Provinsi yang masuk dalam kategori status gizi buruk rendah ada 12 provinsi dimana rata-rata persentasenya sebesar 2.84\%. Provinsi yang masuk dalam kategori status gizi buruk tinggi ada 22 provinsi dengan rata-rata persentasenya sebesar $5.31 \%$.

2. Model gizi buruk balita usia $0-23$ bulan di Indonesia tahun 2018 menggunakan GWLR salah satunya pada Provinsi Maluku dengan pembobot Adaptive Gaussian Kernel adalah sebagai berikut:

$\hat{\pi}=\frac{\exp \left(0.808-0.025 X_{1}+0.035 X_{2}-0.388 X_{3}\right)}{1+\exp \left(0.808-0.025 X_{1}+0.035 X_{2}-0.388 X_{3}\right)}$

Model gizi buruk balita usia 0-23 bulan di Indonesia tahun 2018 menggunakan GWLR salah satunya pada Provinsi Maluku dengan pembobot Adaptive Bisquare Kernel adalah sebagai berikut:

$\hat{\pi}=\frac{\exp \left(-0.253-0.015 X_{1}+0.039 X_{2}-0.666 X_{3}\right)}{1+\exp \left(-0.253-0.015 X_{1}+0.039 X_{2}-0.666 X_{3}\right)}$

Model gizi buruk balita usia 0-23 bulan di Indonesia tahun 2018 menggunakan GWLR salah satunya pada Provinsi Maluku dengan pembobot Adaptive Tricube Kernel adalah sebagai berikut:

$\hat{\pi}=\frac{\exp \left(-0.737-0.009 X_{1}+0.047 X_{2}+0.757 X_{3}\right)}{1+\exp \left(-0.737-0.009 X_{1}+0.047 X_{2}+0.757 X_{3}\right)}$

3. Model terbaik yang dihasilkan menggunakan model GWLR dengan pembobot Adaptive Gaussian Kernel dengan nilai AICc sebesar 31.908.

\section{UCAPAN TERIMA KASIH}

Ucapan terimakasih kami tujukan kepada Laboratorium Statistika UNIMUS, Kementerian Kesehatan RI, Badan Pusat Statistik (BPS) yang telah mensupport data penelitian ini.

\section{REFERENSI}

Adisasmito, W. 2008. Sistem Kesehatan. Jakarta: Persada.

Alamsyah, D., Mexitalia, M., \& Margawati, A. 2015. Beberapa Faktor Risiko Gizi Kurang dan Gizi Buruk Pada Balita 12-59 Bulan. Jurnal Vokasi Kesehatan.

Anggarini, R., \& Purhadi. 2012. Pemodelan Faktor-Faktor Yang Berpengaruh Terhadap Prevalensi Balita Kurang Gizi Di Provinsi Jawa Timur Dengan Pendekatan Geographically Weighted Logistic Regression (GWLR). Sains dan Seni ITS.

Anselin, L. 1988. Spatial Econometrics : Methods and Models. Dordrecht: Kluwer Academic Publishers.

Destyanugraha, R., \& Kurniawan, R. 2017. Pemodelan Angka Kematian Ibu Di Indonesia Dengan Pendekatan Geographically Weighted Poisson Regression.

Dinkes Provinsi Jawa Barat. 2017. Profil Kesehatan Provinsi Jawa Barat Tahun 2016. Bandung: 
Dinas Kesehatan Provinsi Jawa Barat.

Dwinata, A. 2012. Model Regresi Logistik Terboboti Geografis (Studi Kasus : Pemodelan Kemiskinan Di Provinsi Jawa Timur).

Fadli et al. 2018. Pemodelan Geographically Weighted Regression (GWR) Dengan Fungsi Pembobot Tricube Terjadap Angka Kematian Ibu (AKI) Di Kabupaten Kutai Kartanegara Tahun 2015. Jurnal Eksponensial.

Fatimah, E. N. et al. 2015. Pemodelan Risiko Penyakit Pneumonia Pada Balita Di Provinsi Jawa Timur Dengan Pendekatan Geographically Weighted Logistic Regresion. E-Jurnal Matematika, Vol.4 (2).

Fotheringham, et al. 2002. Geographically Weighted Regression. Chichester: John Wiley \& Sons.

Hasriana et al. 2016. Pemodelan Kemiskinan Menggunakan Geographically Weighted Logistic Regression Dengan Fungsi Pembobot Fixed Kernel.

Hosmer, D., \& Lemeshow, S. 1989. Applied Logistic Regression. New York: John Wiley \& Sons.

Kementerian Kesehatan RI. 2019. Profil Kesehatan Indonesia 2018. Jakarta: Kementerian Kesehatan RI.

Kementerian Kesehatan RI. 2016. Hasil Pemantauan Status Gizi (PSG) dan Penjelesannya Tahun 2016. Jakarta: Kementerian Kesehatan RI.

Kementerian Kesehatan RI. 2018. Hasil Utama Riskesdas 2018. Jakarta: Kementerian Kesehatan RI.

Leung, Y. et al 2000. Statistical Test for Spatial Non-Stationerity Based on The Geographically Weighted Regression Model. Environment adn Planning, 9-32.

Muaris, H. 2006. Lauk Bergizi Untuk Anak Balita. Jakarta: Gramedia Pustaka.

Notoatmodjo, S. 2003. Prinsip - Prinsip

Dasar Ilmu Kesehatan Masyarakat. Jakarta: Rineka Cipta

Nugroho, N., \& Slamet, I. 2018. Geographically Weighted Regression Model with Kernel Bisquare and Tricube Weighted Function on Poverty Percentage Data in Central Java Province. Journal of Physics: Conference Series. https://doi.org/10.1088/1742-6596/1025/1/012099.

Sheather, S. 2009. A Modern Approach to Regression with R. New York: Springer.

Umyana. 2018. Perbandingan Regresi Logistik dengan Geographically Weighted Logistic Regression (GWLR) Untuk Pemodelan Gini Ratio Di Jawa Timur Tahun 2016. 